\title{
Oral lesions in older patients: a descriptive analysis of a brazilian population
}

\author{
Lesões orais em pacientes idosos: uma análise descritiva de uma população brasilleira \\ Lesiones orales en ancianos: análisis descritivo de una población brasileña
}

Received: 11/12/2021 | Reviewed: 11/19/2021 | Accept: 11/21/2021| Published: 12/02/2021

\author{
Roberta Freire Almeida \\ ORCID: https://orcid.org/0000-0003-1738-2335 \\ Veiga de Almeida University, Brazil \\ E-mail: robertaf@outlook.com \\ Karla Daniella Malta Ferreira \\ ORCID: https://orcid.org/0000-0002-5787-6412 \\ Veiga de Almeida University, Brazil \\ E-mail: karlamaltaferreira@gmail.com \\ Alexandre Marques Paes da Silva \\ ORCID: https://orcid.org/0000-0001-7559-2555 \\ Estácio de Sá University, Brazil \\ E-mail: xandemps@gmail.com \\ Mayra Stambovsky Vieira \\ ORCID: https://orcid.org/0000-0002-7703-0991 \\ Veiga de Almeida University, Brazil \\ E-mail: mayrastambovsky@hotmail.com \\ Fábio Ramôa Pires \\ ORCID: https://orcid.org/0000-0003-0317-8878 \\ Estácio de Sá University, Brazil \\ E-mail: ramoafop@yahoo.com \\ Beatriz Tholt \\ ORCID: https://orcid.org/0000-0001-7783-3586 \\ Veiga de Almeida University, Brazil \\ E-mail: biatholt@hotmail.com \\ André Luiz Rocha Azevedo \\ ORCID: https://orcid.org/0000-0002-9324-3786 \\ Estácio de Sá University, Brazil \\ E-mail: andrelrazevedo@yahoo.com \\ Teresa Cristina Ribeiro Bartholomeu Santos \\ ORCID: https://orcid.org/0000-0002-1256-5127 \\ Estácio de Sá University, Brazil \\ E-mail: tcnath@terra.com.br \\ Luciana Armada \\ ORCID: https://orcid.org/0000-0002-5877-9657 \\ Estácio de Sá University, Brazil \\ E-mail: luadias@hotmail.com \\ Dennis de Carvalho Ferreira \\ ORCID: https://orcid.org/0000-0003-4166-3284 \\ Estácio de Sá University, Brazil \\ E-mail: denniscf@gmail.com
}

\begin{abstract}
The objective of this retrospective, observational study was to describe the oral lesions diagnosed in older patients through histopathological reports from the oral pathology service of a private university in Rio de Janeiro over a 19 year period (1999-2017) and to call attention to the oral health of the elderly. Information was collected and analyzed from 713 medical records of patients aged $\geq 60$ years old. The data collected included the patient's age, gender and the type and location of the injury. The mean age of the patients was 68.1 years old, with a higher prevalence of lesions in the 60 to 74 age group. The results showed that three of the four most common oral lesions were more frequent in women and only one (oral squamous cell carcinoma) was more common in men. The 4 most common injuries were: fibrous inflammatory hyperplasia $(187 ; 26.2 \%)$, oral squamous cell carcinoma $(78 ; 10.9 \%)$, leukoplakia $(40 ; 5.6 \%)$ and oral lichen planus $(36 ; 5.0 \%)$. These lesions were distributed mainly in the alveolar edge $(71 ; 20.8 \%)$ followed by tongue $(57 ; 16.7 \%)$, bottom of the vestibule $(55 ; 16.1 \%)$, and buccal mucosa $(44 ; 12.9 \%)$. The results obtained should be used to alert health professionals, especially dentists, so that early diagnoses of such lesions can be made and thus contribute to improving the quality of care for the elderly.
\end{abstract}

Keywords: Dental care for aged; Oral pathology; Oral squamous cell carcinoma; Leukoplakia oral; Lichen planus oral; Hyperplasia. 


\begin{abstract}
Resumo
O objetivo deste estudo retrospectivo e observacional foi descrever as lesões bucais diagnosticadas em pacientes idosos por meio de laudos histopatológicos do serviço de patologia bucal de uma universidade privada do Rio de Janeiro em um período de 19 anos (1999-2017) e chamar a atenção à saúde bucal do idoso. As informações foram coletadas e analisadas em 713 prontuários de pacientes com idade $\geq 60$ anos. Os dados coletados incluíram a idade do paciente, $o$ sexo e o tipo e localização da lesão. A idade média dos pacientes foi de 68,1 anos, com maior prevalência de lesões na faixa etária de 60 a 74 anos. Os resultados mostraram que três das quatro lesões orais mais comuns foram mais frequentes em mulheres e apenas uma (carcinoma de células escamosas oral) foi mais comum em homens. As 4 lesões mais comuns foram: hiperplasia fibrosa inflamatória $(187 ; 26,2 \%)$, carcinoma de células escamosas oral (78; 10,9\%), leucoplasia $(40 ; 5,6 \%)$ e líquen plano oral $(36 ; 5,0 \%)$. Essas lesões distribuíram-se principalmente na rebordo alveolar $(71 ; 20,8 \%)$, seguida da língua $(57 ; 16,7 \%)$, fundo de vestíbulo $(55 ; 16,1 \%)$ e mucosa jugal $(44 ; 12,9 \%)$. Os resultados obtidos devem servir para alertar os profissionais de saúde, principalmente os dentistas, para que o diagnóstico precoce dessas lesões possa ser feito e, assim, contribuir para a melhoria da qualidade da assistência ao idoso.

Palavras-chave: Assistência odontológica para idosos; Patologia bucal; Carcinoma de células escamosas oral; Leucoplasia oral; Líquen plano bucal; Hiperplasia.
\end{abstract}

\title{
Resumen
}

El objetivo de este estudio retrospectivo y observacional fue describir las lesiones bucales diagnosticadas en pacientes ancianos a través de informes histopatológicos del servicio de patología bucal de una universidad privada en Río de Janeiro durante un período de 19 años (1999-2017) y llamar la atención sobre la salud bucal de los ancianos. Se recopiló y analizó información de 713 historias clínicas de pacientes $\geq 60$ años. Los datos recopilados incluyeron la edad, el sexo y el tipo y ubicación de la lesión del paciente. La edad media de los pacientes fue de 68,1 años, con mayor prevalencia de lesiones en el grupo de edad de 60 a 74 años. Los resultados mostraron que tres de las cuatro lesiones orales más comunes fueron más frecuentes en mujeres y solo una (Carcinoma de células escamosas de cavidad oral) fue más común en hombres. Las 4 lesiones más frecuentes fueron: hiperplasia fibrosa inflamatoria $(187 ; 26,2 \%)$, carcinoma de células escamosas de cavidad oral $(78 ; 10,9 \%)$, leucoplasia $(40 ; 5,6 \%)$ y liquen plano oral $(36 ; 5,0 \%)$. Estas lesiones se distribuyeron principalmente en el reborde alveolar $(71 ; 20,8 \%)$, seguido de la lengua $(57 ; 16,7 \%)$, fondo del vestíbulo $(55 ; 16,1 \%)$ y mucosa de la mejilla $(44 ; 12,9 \%)$. Los resultados obtenidos deben servir para alertar a los profesionales de la salud, especialmente a los odontólogos, para que se pueda realizar un diagnóstico precoz de estas lesiones y, así, contribuir a mejorar la calidad de la atención al anciano.

Palabras clave: Cuidado dental para ancianos; Patología bucal; Carcinoma de células escamosas de cavidad oral; Leucoplasia bucal; Liquen plano oral; Hiperplasia.

\section{Introduction}

The knowledge of oral and maxillofacial diseases through epidemiological studies plays an important role in Public Health. This knowledge reveals the prevalence and incidence of the diseases, socioeconomic factors, associated risk, as well as the genetic and environmental factors, which can lead to prevention programs through health planning (Bertoja et al., 2007). Various diseases, which can affect the oral cavity, may vary their incidence and intensity according to the patient's age as well as changes in systemic and environmental factors throughout life (Chi et al., 2010). Furthermore, the increasing age of the population represents one of the greatest challenges for contemporary public health, so consequently a correct diagnosis of these lesions is essential (Gutmacher et al., 2016).

Some chronic degenerative disorders associated with aging, such as diabetes mellitus, cardiovascular diseases and osteoporosis, may predispose the elderly to specific oral and maxillofacial changes (Hung et al., 2011). In addition, the loss of teeth and the use of fixed or removable prosthetic appliances increases the frequency of these injuries and, consequently the risk of opportunistic infections, such as candidosis (Gleiznys et al., 2015). Associated with these factors and increasing age, the oral mucosa becomes more susceptible and permeable to substances, facilitating the passage of harmful substances and microorganisms (Cueto et al., 2013). This is also due to a decrease in epithelial renewal, which becomes thinner with age, and a decrease in collagen synthesis by connective tissue that also decreases, resulting in reduced tissue regeneration and resistance to diseases (Espinoza et al., 2003).

The objective of the present study is to present a descriptive analysis of the oral lesions histologically diagnosed in a group of elderly patients attending an oral pathology service at a private University in Rio de Janeiro, Brazil, from 1999 to 2017. 


\section{Methodology}

This study was carried out after approval by the Ethics Committee in Research - UVA (No. 2701609). The methods used in this retrospective and observational study were based on the studies of Mohan et al. (2016) and Silva et al. (2017). All patients diagnosed with oral lesions submitted to histological analysis at the Oral Pathology Laboratory, Estácio de Sá University, Rio de Janeiro, Brazil, from January 1999 to December 2017 were part of the initial sample. The files of the laboratory were reviewed and all patients who were 60 years old and more were selected. Their individual laboratory forms were analyzed and all cases with a final diagnosis and the required clinical information available were retrieved for the final sample.

The sample consisted of histopathological reports and the data collected were: age, gender, location of the lesion and histopathological diagnosis provided by oral pathologists with more than 15 years of experience in histopathological diagnoses. These variables were analyzed separately for each final diagnosis and the data were tabulated. All final diagnosis were quantified according to the World Health Organization (WHO) disease classification and the most prevalent were separated by gender. Cases with records lacking three or more items (insufficient data) and reports presenting aspects of normality or without conclusive diagnosis were excluded.

The patients was categorized into 3 age groups: young-old (60-74 years), old-old (75-85 years) and oldest-old (>85 years) following a previously published study (Pomorska-Wesolowka et al., 2017). A database of the information collected was made on spreadsheets in Microsoft Office Excel®. Statistics were performed using the IBM SPSS software package, version 21.0 for Windows (SPSS, Chicago, IL, USA). A descriptive analysis was then performed using tables, and for some variables the values were compared by the Chi-square and Fisher's Exact tests, with a significance level of 5\% ( $\mathrm{p}<0.05)$.

\section{Results}

A total of 713 histological reports composed the final sample, of which 456 were female $(64.0 \%)$ and 257 were male (36.0\%). The mean age of the patients was 68.1 years old (68.2 for females and 67.8 for males), ranging from 60 to 91 years old. Table 1 shows the frequency of the oral lesions observed in the sample and showed that inflammatory fibrous hyperplasia (IFH, 187, 26.1\%), squamous cell carcinoma (OSCC, 78, 10.9\%), leukoplakia (OL, 40, 5.6\%) and lichen planus (LP, 36, 5.0\%) were the four most common lesions.

Table 1. Frequency of all lesions diagnosed in the study sample $(n=713)$.

\begin{tabular}{lcc}
\hline Lesions & $\mathbf{N}$ & $\%$ \\
\hline Inflammatory fibrous hyperplasia & 187 & 26.1 \\
Squamous cell carcinoma & 78 & 10.9 \\
Leukoplakia & 40 & 5.6 \\
Lichen planus & 36 & 5.0 \\
Periapical cyst & 31 & 4.3 \\
Periapical granuloma & 26 & 3.6 \\
Pyogenic granuloma & 22 & 3.1 \\
Traumatic fibroma & 20 & 2.9 \\
Malignant neoplasm (except OSCC) & 17 & 2.4 \\
Squamous papilloma & 13 & 1.8 \\
Lichenoid lesion & 10 & 1.4 \\
Actinic cheilitis & 8 & 1.1
\end{tabular}




\begin{tabular}{lcc} 
Amalgam tattoo & 8 & 1.1 \\
Melanotic macule & 8 & 1.1 \\
Others odontogenic cysts & 8 & 1.1 \\
Mucocele & 6 & 0.8 \\
Ameloblastoma & 5 & 0.7 \\
Fibrolipoma & 5 & 0.7 \\
Florida cement-osseous dysplasia & 5 & 0.7 \\
Odontogenic tumours & 5 & 0.7 \\
Paracoccidioidomycosis & 5 & 0.7 \\
Traumatic neuroma & 5 & 0.7 \\
Gingival hyperplasia & 4 & 0.6 \\
Hyperplasia of foliated papillae & 4 & 0.6 \\
Leukoerythroplakia & 4 & 0.6 \\
Pleomorphic adenoma & 4 & 0.6 \\
Sialodenitis & 4 & 0.6 \\
Varicosity & 713 & 0.6 \\
Others & 4 & 19.6 \\
\hline & 41 & \\
\hline
\end{tabular}

Abbreviation: OSCC, Oral Squamous Cell Carcinoma. Source: Authors.

There were 577 patients $(80.9 \%)$ in the young-old group, $119(16.7 \%)$ in the old-old group (75-85 years) and 17 (2,4\%) in the oldest-old group. Table 2 shows the distribution of the four most common disease groups by gender and age. Notably, the majority of the lesions diagnosed were in patients between 60 and 74 years old. No variable showed statistical significance according to age and gender.

Table 2. Comparison between the age and sex of the most frequent lesions found in this study.

\begin{tabular}{|c|c|c|c|c|c|c|c|c|c|c|c|c|}
\hline & \multicolumn{3}{|c|}{$\begin{array}{c}\text { Fibrous inflammatory } \\
\text { hyperplasia }^{a}\end{array}$} & \multicolumn{3}{|c|}{ Squamous cell carcinoma ${ }^{b}$} & \multicolumn{3}{|c|}{ Leukoplakia $^{c}$} & \multicolumn{3}{|c|}{ Oral lichen planus $^{d}$} \\
\hline & Female & Male & Total & Female & Male & Total & Female & Male & Total & Female & Male & Total \\
\hline $\begin{array}{c}\text { Age } \\
\text { (mean) }\end{array}$ & & $67.3(60-88)$ & & & $69.4(60-87)$ & & & $70.3(60-86)$ & & & $68.9(60-87)$ & \\
\hline $\begin{array}{l}60-74 \\
\text { years }\end{array}$ & $\begin{array}{c}130 \\
(69.5 \%)\end{array}$ & $\begin{array}{c}31 \\
(16.6 \%)\end{array}$ & $\begin{array}{c}161 \\
(86.1 \%)\end{array}$ & $\begin{array}{c}14 \\
(17.9 \%)\end{array}$ & $\begin{array}{c}47 \\
(60.3 \%)\end{array}$ & $\begin{array}{c}61 \\
(78.2 \%)\end{array}$ & $\begin{array}{c}21 \\
(52.5 \%)\end{array}$ & $6(15 \%)$ & $\begin{array}{c}27 \\
(67.5 \%)\end{array}$ & $\begin{array}{c}22 \\
(61.1 \%)\end{array}$ & $\begin{array}{c}5 \\
(13.9 \%)\end{array}$ & $27(75 \%)$ \\
\hline $\begin{array}{l}75-85 \\
\text { years }\end{array}$ & $\begin{array}{c}18 \\
(9.6 \%)\end{array}$ & $\begin{array}{c}5 \\
(2.7 \%)\end{array}$ & $\begin{array}{c}23 \\
(12.3 \%)\end{array}$ & $\begin{array}{c}5 \\
(6.4 \%)\end{array}$ & $\begin{array}{c}11 \\
(14.1 \%)\end{array}$ & $\begin{array}{c}16 \\
(20.5 \%)\end{array}$ & $\begin{array}{c}6 \\
(15 \%)\end{array}$ & $\begin{array}{c}5 \\
(12.5 \%)\end{array}$ & $\begin{array}{c}11 \\
(27.5 \%)\end{array}$ & $\begin{array}{c}7 \\
(19.4 \%)\end{array}$ & $\begin{array}{c}1 \\
(2.8 \%)\end{array}$ & $\begin{array}{c}8 \\
(22.2 \%)\end{array}$ \\
\hline $\begin{array}{l}>85 \\
\text { years }\end{array}$ & $\begin{array}{c}3 \\
(1.6 \%)\end{array}$ & $0(0 \%)$ & $\begin{array}{c}3 \\
(1.6 \%)\end{array}$ & $\begin{array}{c}1 \\
(1.3 \%)\end{array}$ & $0(0 \%)$ & $\begin{array}{c}1 \\
(1.3 \%)\end{array}$ & $2(5 \%)$ & $\begin{array}{c}0 \\
(0 \%)\end{array}$ & $2(5 \%)$ & $\begin{array}{c}1 \\
(2.8 \%)\end{array}$ & $0(0 \%)$ & $\begin{array}{c}1 \\
(2.8 \%)\end{array}$ \\
\hline $\begin{array}{c}\text { Tota } \\
\text { l }\end{array}$ & $\begin{array}{c}151 \\
(80.7 \%)\end{array}$ & $\begin{array}{c}36 \\
(19.3 \%)\end{array}$ & $\begin{array}{c}187 \\
(100 \%)\end{array}$ & $\begin{array}{c}20 \\
(35.6 \%)\end{array}$ & $\begin{array}{c}58 \\
(74.4 \%)\end{array}$ & $\begin{array}{c}68 \\
(100 \%)\end{array}$ & $\begin{array}{c}29 \\
(72.5 \%)\end{array}$ & $\begin{array}{c}11 \\
(27.5 \%)\end{array}$ & $\begin{array}{c}4 \\
(100 \%)\end{array}$ & $\begin{array}{c}30 \\
(\mathbf{8 3 . 3 \%})\end{array}$ & $\begin{array}{c}6 \\
(16.7 \%)\end{array}$ & $\begin{array}{c}36 \\
(100 \%)\end{array}$ \\
\hline
\end{tabular}


Table 3 shows the distribution of the four most common oral lesions. For IFH, the most commonly affected sites were bottom of the vestibule (50 lesions, 26.7\%), the alveolar ridge (40,21.4\%), and the lips (24, 12.8\%). For OSCC, the most commonly affected regions were the tongue $(24,30.8 \%)$, palate $(15,19.2 \%)$, mouth floor $(13,16.7 \%)$, and alveolar edge $(11$, $14.1 \%)$. OSCC mostly affected males (58 cases, 74.4\%). For OL, the most commonly affected region was the alveolar edge (13 lesions, $32.5 \%)$, which was followed by buccal mucosa $(10,25 \%)$, tongue $(8,20 \%)$, and floor of mouth $(5,12.5 \%)$. Location was not properly described in 39 cases. OL was the only variable that showed statistical significance ( $\mathrm{p}=0.006)$ according to location and gender.

Table 3. Comparison between the location and sex of the most frequent lesions found in this study.

\begin{tabular}{|c|c|c|c|c|c|c|c|c|c|c|c|c|}
\hline \multirow[b]{2}{*}{ Location } & \multicolumn{3}{|c|}{$\begin{array}{c}\text { Fibrous inflammatory } \\
\text { hyperplasia }^{a}\end{array}$} & \multicolumn{3}{|c|}{ Squamous cell carcinoma ${ }^{b}$} & \multicolumn{3}{|c|}{ Leukoplakia $^{c}$} & \multicolumn{3}{|c|}{ Oral lichen planus ${ }^{d}$} \\
\hline & Female & Male & Total & Female & Male & Total & Female & Male & Total & Female & Male & Total \\
\hline $\begin{array}{l}\text { Alveolar } \\
\text { edge }\end{array}$ & $\begin{array}{c}30 \\
(16 \%)\end{array}$ & $\begin{array}{c}10 \\
(5.3 \%)\end{array}$ & $\begin{array}{c}40 \\
(21.4 \%)\end{array}$ & $\begin{array}{c}4 \\
(5.1 \%)\end{array}$ & $\begin{array}{c}7 \\
(9 \%)\end{array}$ & $\begin{array}{c}11 \\
(14.1 \%)\end{array}$ & $\begin{array}{c}10 \\
(25 \%)\end{array}$ & $\begin{array}{c}3 \\
(7.5 \%)\end{array}$ & $\begin{array}{c}13 \\
(32.5 \%)\end{array}$ & $\begin{array}{c}7 \\
(19.4 \%)\end{array}$ & $\begin{array}{c}0 \\
(0 \%)\end{array}$ & $\begin{array}{c}7 \\
(19.4 \%)\end{array}$ \\
\hline $\begin{array}{c}\text { Bottom } \\
\text { of the } \\
\text { vestibule }\end{array}$ & $\begin{array}{c}42 \\
(22.5 \%)\end{array}$ & $\begin{array}{c}8 \\
(4.3 \%)\end{array}$ & $\begin{array}{c}50 \\
(26.7 \%)\end{array}$ & $\begin{array}{c}1 \\
(1.3 \%)\end{array}$ & $\begin{array}{c}2 \\
(2.6 \%)\end{array}$ & $3(3.8 \%)$ & $0(0 \%)$ & $0(0 \%)$ & $0(0 \%)$ & $2(5.6 \%)$ & $\begin{array}{c}0 \\
(0 \%)\end{array}$ & $2(5.6 \%)$ \\
\hline $\begin{array}{l}\text { Buccal } \\
\text { mucosa }\end{array}$ & $\begin{array}{c}14 \\
(7.5 \%)\end{array}$ & $0(0 \%)$ & $\begin{array}{c}14 \\
(7.5 \%)\end{array}$ & $\begin{array}{c}1 \\
(1.3 \%)\end{array}$ & $3(3.8 \%)$ & $\begin{array}{c}4 \\
(5.1 \%)\end{array}$ & $\begin{array}{c}4 \\
(10 \%)\end{array}$ & $\begin{array}{c}6 \\
(15 \%)\end{array}$ & $\begin{array}{c}10 \\
(25 \%)\end{array}$ & $\begin{array}{c}12 \\
(33.3 \%)\end{array}$ & $\begin{array}{c}4 \\
(11.1 \%)\end{array}$ & $\begin{array}{c}16 \\
(44.4 \%)\end{array}$ \\
\hline $\begin{array}{l}\text { Floor of } \\
\text { mouth }\end{array}$ & $\begin{array}{c}3 \\
(1.6 \%)\end{array}$ & $\begin{array}{c}0 \\
(0 \%)\end{array}$ & $\begin{array}{c}3 \\
(1.6 \%)\end{array}$ & $\begin{array}{c}3 \\
(3.8 \%)\end{array}$ & $\begin{array}{c}10 \\
(12.8 \%)\end{array}$ & $\begin{array}{c}13 \\
(16.7 \%)\end{array}$ & $\begin{array}{c}5 \\
(12.5 \%)\end{array}$ & $0(0 \%)$ & $\begin{array}{c}5 \\
(12.5 \%)\end{array}$ & $0(0 \%)$ & $0(0 \%)$ & $0(0 \%)$ \\
\hline Lips & $\begin{array}{c}18 \\
(9.6 \%)\end{array}$ & $\begin{array}{c}6 \\
(3.2 \%)\end{array}$ & $\begin{array}{c}24 \\
(12.8 \%)\end{array}$ & $\begin{array}{c}1 \\
(1.3 \%)\end{array}$ & $6(7.7 \%)$ & $7(9 \%)$ & $0(0 \%)$ & $2(5 \%)$ & $2(5 \%)$ & $0(0 \%)$ & $0(0 \%)$ & $0(0 \%)$ \\
\hline Palate & $\begin{array}{c}16 \\
(8.6 \%)\end{array}$ & $\begin{array}{c}3 \\
(1.6 \%)\end{array}$ & $\begin{array}{c}19 \\
(10.2 \%)\end{array}$ & $\begin{array}{c}4 \\
(5.1 \%)\end{array}$ & $\begin{array}{c}11 \\
(14.1 \%)\end{array}$ & $\begin{array}{c}15 \\
(19.2 \%)\end{array}$ & $2(5 \%)$ & $0(0 \%)$ & $2(5 \%)$ & $0(0 \%)$ & $0(0 \%)$ & $0(0 \%)$ \\
\hline $\begin{array}{c}\text { Retromol } \\
\text { ar }\end{array}$ & $0(0 \%)$ & $\begin{array}{c}1 \\
(0.5 \%)\end{array}$ & $\begin{array}{c}1 \\
(0.5 \%)\end{array}$ & $0(0 \%)$ & $1(1.3 \%)$ & $1(1.3 \%)$ & $0(0 \%)$ & $0(0 \%)$ & $0(0 \%)$ & $0(0 \%)$ & $0(0 \%)$ & $0(0 \%)$ \\
\hline Tongue & $\begin{array}{c}12 \\
(6.4 \%)\end{array}$ & $\begin{array}{c}3 \\
(1.6 \%)\end{array}$ & $\begin{array}{c}15 \\
(8 \%)\end{array}$ & $\begin{array}{c}6 \\
(7.7 \%)\end{array}$ & $\begin{array}{c}18 \\
(23.1 \%)\end{array}$ & $\begin{array}{c}24 \\
(30.8 \%)\end{array}$ & $\begin{array}{c}8 \\
(20 \%)\end{array}$ & $0(0 \%)$ & $\begin{array}{c}8 \\
(20 \%)\end{array}$ & $\begin{array}{c}8 \\
(22.2 \%)\end{array}$ & $\begin{array}{c}2 \\
(5.6 \%)\end{array}$ & $\begin{array}{c}10 \\
(27.8 \%)\end{array}$ \\
\hline NI & $\begin{array}{c}16 \\
(8.6 \%)\end{array}$ & $5(1.6 \%)$ & $\begin{array}{c}21 \\
(11.2 \%)\end{array}$ & $0(0 \%)$ & $0(0 \%)$ & $0(0 \%)$ & $0(0 \%)$ & $0(0 \%)$ & $0(0 \%)$ & $1(2.8 \%)$ & $0(0 \%)$ & $1(2.8 \%)$ \\
\hline Total & $\begin{array}{c}151 \\
(80.7 \%)\end{array}$ & $\begin{array}{c}36 \\
(19.3 \%)\end{array}$ & $\begin{array}{c}187 \\
(100 \%)\end{array}$ & $\begin{array}{c}20 \\
(25.6 \%)\end{array}$ & $\begin{array}{c}58 \\
(74.4 \%)\end{array}$ & $\begin{array}{c}78 \\
(100 \%)\end{array}$ & $\begin{array}{c}29 \\
(72.5 \%)\end{array}$ & $\begin{array}{c}11 \\
(27.5 \%)\end{array}$ & $\begin{array}{c}40 \\
(100 \%)\end{array}$ & $\begin{array}{c}30 \\
(83.3 \%)\end{array}$ & $\begin{array}{c}6 \\
(16.7 \%)\end{array}$ & $\begin{array}{c}36 \\
(100 \%)\end{array}$ \\
\hline
\end{tabular}

${ }^{\mathrm{a}} \chi^{2}(\mathrm{p}=0.239) ;{ }^{\mathrm{b}} \chi^{2}(\mathrm{p}=0.977) ;{ }^{\mathrm{c}} \chi^{2}(\mathrm{p}=0.006) ;{ }^{\mathrm{d}} \chi^{2}(\mathrm{p}=0.578)$. NI: Not Informed. Source: Authors.

\section{Discussion}

The data obtained in this study demonstrated that the most prevalent lesions in the elderly patients investigated were FIH, OSSC, leukoplakia and oral lichen planus in this order. In the present study $26.1 \%$ of the injuries found were FIH, which agrees with other studies that also found FIH as the most prevalent lesion in the elderly (Mohan et al., 2016; Dhanuthai et al., 2016) and with the averages presented in other epidemiological surveys such as Bertoja et al. (2007) with 30.65\%. The prevalence of this lesion may be attributed to the prolonged use of poorly adapted removable prosthesis, which justifies its frequent location 
in the vestibule and alveolar mucosa (Bertoja et al., 2007). Its high frequency demonstrates the importance of periodic clinical monitoring along with guidance on oral hygiene habits and possible replacement of dental prosthesis when necessary (Moresco, Nora Filho e Balbinot, 2003).

Among the other lesions recorded, $10.9 \%$ cases of OSSC, 5.6\% cases of leukoplakia and 5.0\% cases of oral lichen planus were observed. According to WHO (2005), more than $90 \%$ of malignant neoplasms of the oral cavity are squamous cell carcinomas with a predominance in males. Moresco, Nora Filho e Balbinot (2003) found a lower frequency of OSCC (3.48\%), in this study, the OSCC lesions were more common in male patients aged from 60 to 74 years old (60.3\%). These authors pointed out the need for government actions to provide support for early diagnosis, due to the morbidity and mortality of patients diagnosed with OSCC (Moresco, Nora Filho e Balbinot, 2003). The etiology of cancer of the oral cavity is multifactorial, with tobacco, high alcohol consumption and excessive exposure to ultraviolet solar radiation being reported as high risk factors. HPV infection, a diet deficient in fruits and vegetables, and poor oral hygiene have been studied as implication factors in carcinogenesis, especially on tongue and oropharynx cancer cases (Montero e Patel, 2015). In addition, there is a significant increase in the incidence of cases of OSCC in elderly individuals that may be related to the increase in longevity of mankind.

Mosele et al. (2008) reported highest prevalence in seventh decade patients. Furthermore, the work of Chen et al. (1991), registered 9,708 cases of oral cancer, with higher incidence in the eighth decade of life, and more frequently in males, who represented $74 \%$ of the cases. The locations with the highest occurrence of carcinoma in their work were tongue (41.8\%), followed by the oral floor (25.8\%) and palate (13.2\%), respectively, similar with this study.

Our study demonstrated that malignant oral lesions represented 13.3\% (10.9\% OSCC; 2.4\% Others). Rahib et al (2021) reported an estimated projection of US cancer incidence and death to 2040. In this study the authors claimed that malignant neoplasms are the leading cause of death in individuals aged 45 to 64 years in 2020 and a substantial proportion of health care spending is attributed to cancer. We agree with these authors that the changing demographic characteristics in each country must be considered when a prevalence disease study is carried out as incidence and death rates for many cancer types vary by age, sex and ethnicity. An observational study like the present one can represent an important guide to a future projection of incidence lesions in Brazilian population and may alter the health care burden by guiding funding allocations, health care planning and health public policy efforts.

Further attention and care are needed to ensure early diagnosis in older patients to reduce co-morbidities and to optimize the management of major complications resulting from anti-neoplastic treatments (Bezerra et al., 2018). According to Bezerra et al. (2018), the distribution of oral cancer in Brazil shows a high prevalence of advanced stage (grade IV), with neoplastic lesions in tongue. This profile confirms the previous findings in the literature and shows up the greater aggressiveness of oral cancer, especially when located at the base of the tongue, in alcoholics and smokers. In Brazil, there has been an increase in oral cancer registries that may be related to the incentive of the National Oral Health Policy (Smiling Brazil) to the implantation and expansion of the network information for early diagnosis.

OSCC constitute more than $90 \%$ of all oral cancer. Other malignant tumors can arise from the epithelium, connective tissue, minor salivary glands, lymphoid tissue, and melanocytes or metastasis from a distant tumor. A variety of premalignant lesions have been associated with development of OSCC. The more common premalignant lesions including leukoplakia, erythroplakia, oral lichen planus, and oral submucous fibrosis have varying potential for malignant transformation (Montero e Patel, 2015). The WHO classifies premalignant lesions according to degree of dysplasia into mild, moderate, severe, and carcinoma in situ. Leukoplakia is a clinical term defined as a "white patch or plaque" that cannot be characterized clinically or pathologically as any other disease. Leukoplakia disorder is classified by WHO (2005) with malignant potential, which, in our study was the third most prevalent with 40 cases (5.6\%). Tobacco consumption is the factor most associated with its presence despite having a multifactorial etiology. Its risk factors are common to OSCC with a predilection for males over 40 years old 
(Montero e Patel, 2015). However, in our study, this pathology was predominant in females and in the age range of 60 to 74 years old $(52.5 \%)$. This result is close to the finding of Silveira et al. (2009), in which $62.8 \%$ of women were diagnosed with leukoplakia and who had a mean age of 54.0 years old.

In this study, the highest prevalence rate of the four most frequent lesions was in the 60-74 year old group (80.9\%). This may be justified by the fact that Brazil is a developing country, with a lower life expectancy than a developed country. An example of this was confirmed in relation to the Human Development Index, comparing the life expectancy of the population of Norway (82.4 years) with that of Brazil (75.9 years) (United Nations, 2020). In spite of the demographic changes that the country is going through (from 2005 to 2015, the percentage of the elderly of 60 years old or more in the Brazilian population rose from 9.8\% to $14.3 \%$, according to Brazilian Institute of Geography and Statistics - IBGE data, in 2016) however, the average age of the elderly in Brazil is still lower than that of developed countries.

In this study, we considered the age groups according to WHO (2005), and the elderly age group of 60 years old or more is the fastest growing group in Brazil (IBGE, 2021). This age group may present oral lesions due to aging, the use of maladaptive prostheses and poor oral hygiene (De Visschere et al., 2011). The mean age of the patients who participated in this study was 68.1 years old and was similar to the study by Silva et al. (2017), where the mean age was 69.0 years old and Carvalho et al. (2011), where the mean age was 68.4 years old; both studies were carried out in Brazil $(9,25)$. These results differ from the ones of Dhanuthai et al. (2016), whose biopsies were performed in the Oral Pathology Departments of institutions in Thailand, South Korea, Japan, Islamic Republic of Iran and Canada, and showed a mean age of 73.0 years old.

The findings of the present study showed a relationship with the study of Corrêa et al. (2006), who analyzed 2.250 histopathological reports of oral lesions in elderly patients, aged 60 years old and over, with the presence of $11.5 \%$ of malignant epithelial lesions in elderly patients. These authors also reported a $266 \%$ increase in cases of oral cancer between 2005 and 2006 , demonstrating that this increase can be explained by the underreporting of oral cancer in 2005. The study of Llewellyn et al. (2004), presented a distinct result demonstrating that $52.0 \%$ of patients diagnosed with oral cancer were between 41 and 45 years old. The authors related their findings to exposure to tobacco and alcohol, which favor the occurrence of oral cancer (Llewellyn et al., 2004).

In our results, we found that more than half of the biopsies were from female subjects $(64.0 \%)$. Similar data were observed by Alencar (2017), who studied the prevalence of oral lesions in 80 elderly patients who attended a Senior Citizen's Convenience Center in the Federal District (Brazil) and found 71.0\% were females. Silva et al. (2017) also reported that 59.4\% of the 7.259 elderly patients included in their study were females. In contrast, Araújo et al. (2014) reported a higher frequency of oral pathological changes in males, who had a high rate of malignant neoplasms and potentially malignant disorders associated with a high tobacco usage. A plausible explanation for the greater number of diagnoses in female patients may be because women generally have greater concern for their health, well-being and esthetics in comparison to men and, thus, seek for health services for diagnosis and treatment of such lesions more frequently detected (Araujo et al., 2014).

The most frequent locations of the four most common oral lesions were the alveolar edge (ridge) (20.8\%) followed by tongue $(16.7 \%)$, bottom of the vestibule (16.1\%), and buccal mucosa (12.9\%). Durazzo et al. (2005), from a review of medical records between 1994 and 2002, found that most patients had lesions on the tongue and / or floor of the mouth (55.6\%) and $20.3 \%$ on the lips. In addition, they found that OSCC was the most frequently found in $90.3 \%$ of cases, followed by glandular carcinoma in 4.0\%. The work of Mosele et al. (2008) also verified, through the analysis of histopathological reports with diagnoses of OSCC that $77.5 \%$ of the cases were male, the predominant age group was between 50 and 59 years old and $68 \%$ were caucasian. Furthermore, the lower lip was the most affected site (23.7\%), followed by the oral floor (18.7\%) and tongue $(17.5 \%)$.

Among the limitations of the present study are: the patients in this study were not a profile of patients who are comonly 
treated at the university clinic, since they were referred to the university by a dentist after biopsy; the prevalence of oral lesions may be underestimated, since they can only be diagnosed clinically, not through biopsy, and in some cases clinical information was absent from the histopathological records of the patients.

This study, considering the current growth of the elderly population, sought to contribute a wake-up-call in terms of the oral aspects of these patients and the most frequent oral lesions based on a group of elderly patients from Rio de Janeiro. Thus, intervention strategy programs should be carried out by dental surgeons in order to prevent or minimize the effect of such injuries and primary and secondary prevention of oral cancer requires better education about lifestyle related risk factors, and improved awareness and tools for early diagnosis.

\section{Conclusion}

In conclusion, the most frequently diagnosed oral lesions were: fibrous inflammatory hyperplasia, at the bottom of the vestibule; oral squamous cell carcinoma on the tongue; Leukoplakia on the alveolar edge and oral Lichen Planus on buccal mucosa. Almost all except one (fibrous inflammatory hyperplasia) of the four most common lesion are oral cancer or oral cancer related lesion. There was a higher prevalence of lesions in females. It would be interesting, in future research, to monitor patients diagnosed with premalignant lesions in order to describe those who had a recurrence or even malignancy, correlating to clinical and pathological factors.

\section{References}

Alencar, J. A. (2017). Prevalência de lesões bucais em idosos assistidos no Centro de Convivência do Idoso - Gama - DF. Dissertation (Master in Gerontology) - Universidade Católica de Brasília.

Araujo M. V. A., Pinheiro H. H. C., Pinheiro J. J. V., Quaresma J. A., Fuzii H. T. \& Medeiros R. C. (2014). Prevalence of human papillomavirus (HPV) in Belém, Pará State, Brazil, in the oral cavity of individuals without clinically diagnosable injuries. Cad. Saúde Pública. 30(5):1115-9.

Bertoja I. C., Tomazini J. G., Braosi A. P. R., Zielak J. C., Reis L. F. G. \& Giovanini A. F. (2007). Prevalência de lesões bucais diagnosticadas pelo Laboratório de Histopatologia do UnicenP. RSBO. 4(2): 41-6.

Bezerra N. V., Leite K. L., de Medeiros M. M., Martins M. L., Cardoso A. M., Alves P. M., et al. (2018). Impact of the anatomical location, alcoholism and smoking on the prevalence of advanced oral cancer in Brazil. Med Oral Patol Oral Cir Bucal. 1;23(3):e295-e301.

Carvalho M. V., Iglesias D. P., Nascimento G. J. \& Sobral A. P. (2011). Epidemiological study of 534 biopsies of oral mucosal lesions in elderly Brazilian patients. Gerodontology. 28(2):111-5.

Chi A. C., Neville B. W., Krayer J. W. \& Gonsalves W. C. (2010). Oral Manifestations of Systemic Disease. Am Fam Physician. 82(11):1381-1388.

Chen J. K.,Eisenberg E., Krutchkoff D. J. \& Katz R. V. (1991). Changing Trends in oral câncer in United States, 1935 to 1985 ; A Connecticut Study. J Oral Maxillofac. Surg. 49(11):1152-8.

Corrêa L., Frigerio M. L., Sousa S. C. \& Novelli M. D. (2006). Oral lesions in elderly population: A biopsy survey using 2250 histopathological records. Gerodontology. 23(1):48-54.

Cueto A., Martínez R., Niklander S., Deichler J., Barraza A. \& Esguep A. (2013). Prevalence of oral mucosal lesions in an elderly population in the city of Valparaiso, Chile. Gerodontology. 30(3):201-6.

De Visschere L. M., Van der Putten G. J., Vanobbergen J. N., Schols J. M. \& de Baat C. (2011). An oral health care guideline for institutionalised older people. Gerodontology. 28(4):307-10.

Dhanuthai K., Rojanawatsirivej S., Somkotra T., Shin H. I., Hong S. P., Darling M., et al. (2016). Geriatric oral lesions: A multicentric study. Geriatr Gerontol Int. 16(2):237-43.

Durazzo M. D., Araujo C. E. N., Brandão Neto J. S., Potenza A. S., Costa P., Takeda F., et al. (2005). Clinical and epidemiological features of oral cancer in medical school teaching hospital from 1994 to 2002: increasing incidence in women, predominance of advanced local disease, and low incidence of neck metastases. Clinics. 60(4):293-298.

Espinoza I., Rojas R., Aranda W. \& Gamonal J. (2003). Prevalence of oral mucosal lesions in elderly people in Santiago, Chile. J Oral Pathol Med. 32(10):5715.

Gleiznys A., Zdanavičienė E. \& Žilinskas J. (2015). Candida albicans importance to denture wearers. A literature review. Stomatologija. Baltic Dental and Maxillofacial Journal. 17(2):54-66. 
Gutmacher Z., Teich S., Lin S., Ghantous Y. \& Abu El-Naaj I. (2016). Practitioners' challenges in diagnosing oral and maxillofacial tumors. Quintessence Int. 47(7):603-608

Hung W. W., Ross J. S., Boockvar K. S. \& Sir A. L. (2011). Recent trends in chronic disease, impairment and disability among older adults in the United States. BMC Geriatr. 11:47.

Instituto Brasileiro de Geografia e Estatística - IBGE. Censo Demográfico. (2010). Available in: https://www.ibge.gov.br/estatisticas/sociais/populacao/9662censo-demografico-2010.html?=\&t=resultados. Accessed in: Oct 31, 2021.

Instituto Brasileiro de Geografia e Estatística - IBGE. Projeção da população do Brasil e das Unidades de Federação. (2021). Available in: https://www.ibge.gov.br/apps/populacao/projecao/. Accessed in: Oct 31, 2021.

Llewellyn C. D., Linklater K., Bell J., Johnson N. W. \& Warnakulasuriya S. (2004). An analysis of risk factors for oral cancer in young people: a case-control study. Oral Oncol. 40(3):304-13.

Mohan B. C., Angadi P. V., Hallikerimath S. \& Kale A. D. (2016). Diagnoses of 964 oral biopsies from people aged over 50 years in Karnataka State, India. Gerodontology. 33(2):217-24.

Montero P. H. \& Patel S. G. (2015). Cancer of the oral cavity. Surg Oncol Clin N Am. 24(3):491-508.

Moresco F. C., Nora Filho M. R. \& Balbinot M. A. (2003). Levantamento epidemiológico dos diagnósticos histopatológicos da disciplina de Estomatologia da Faculdade de Odontologia da ULBRA - Canoas/RS. Stomatos. 9(17): 29-34.

Mosele J. C., Stangles L. P., Trntin M. S., Silva S. O. \& Carli J. P. (2008). Levantamento epidemiológico dos casos de carcinoma epidermoide da cavidade bucal registrados no serviço de diagnóstico histopatológico do Instituto de Ciências Biológicas da Universidade de Passo Fundo/RS. Revista Odonto. 16(32):18-24.

Pomorska-Wesołowska M., Różańska A., Natkaniec J., Gryglewska B., Szczypta A., Dzikowska M., et al. (2017). Longevity and gender as the risk factors of methicillin-resistant Staphylococcus aureus infections in southern Poland. BMC Geriatr. 10;17(1):51.

Rahib L., Wehner M. R., Matrisian L. M. \& Nead K. T. (2021). Estimated Projection of US Cancer Incidence and Death to 2040. JAMA. 4(4):e214708.

Silva L. P., Leite R. B., Sobral A. P. V., Arruda J. A., Oliveira L. V., Noronha M. S., et al. (2017). Oral and maxillofacial lesions diagnosed in older people of a brazilian population: a multicentric study. J Am Geriatr Soc. 65(7):1586-1590.

Silveira E. J. D., Lopes M. F. F., Silva L. M. M., Ribeiro B. F., Lima K. C. \& Queiroz L. M. G. (2009). Lesões orais com potencial de malignização: análise clínica e morfológica de 205 casos. J. Bras. Patol. Med. Lab. 45(3):233-238, 2009.

Thiagarajan S., Nair S., Nair D., Chaturvedi P., Kane S. V., Agarwal J. P., et al. (2014). Predictors of prognosis for squamous cell carcinoma of oral tongue. $J$ Surg Oncol. 109(7):639-44.

United Nations (2020). Human Development Index. Available in: http://hdr.undp.org/en/data. Accessed in: Oct 31, 2021.

World Health Organization (2005). World Health Organization Classification of Tumours. Pathology \& Genetics. Head and Neck Tumours. Lyon: International Agency for Research on Cancer (IARC) IARC Press. P. 177-9. 